\title{
Impulsy ze strony teologicznej myśli Karla Rahnera SJ (1904-1984) i teologii narracyjnej w kierunku pogłębienia teologii imienia Jezus
}

\section{Założenia formalno-treściowe}

Do podstawowych treści wiary chrześcijańskiej należy uznanie Jezusa z Nazaretu za prawdziwego Boga i prawdziwego człowieka. Ojcowie Soboru Chalcedońskiego, odbytego w 451 roku, ujęli tę naukę w postać twierdzenia o unii hipostatycznej: jeden i ten sam odwieczny Syn Boży, Boski Logos istnieje w dwóch pełnych naturach - Boskiej i ludzkiej, ten sam w Bóstwie, ten sam w człowieczeństwie. Połączenie obu natur następuje mocą jednej jedynej Osoby - Drugiej Osoby Trójcy Świętej, Syna Bożego i trwa wiecznie ${ }^{2}$. Stając się człowiekiem, odwieczny Syn Boży przyjął całkowitą naturę ludzką. Konsekwencją tego faktu jest to, że jako człowiek Syn Boży podlegał temu wszystkiemu, co ludzkie. Mieści się w tym nadanie Mu jako człowiekowi imienia: „Gdy nadszedł dzień ósmy i należało obrzezać Dziecię, nadano Mu imię Jezus, którym Je nazwał anioł, zanim się poczęło w łonie [Matki]" (Łk 2,21). Imię pozwalało identyfikować wcielonego Syna Bożego jako Jezusa z Nazaretu, co podkreślało prawdziwość Jego człowieczeństwa.

Jest rzeczą powszechnie znaną, że w kulturze semickiej imię wiąże się ściśle z tożsamością osoby je noszącej. W imieniu Jezus zawarte jest imię Boga oraz cel posłannictwa Mesjasza, który wcielił się w ludzką naturę po to, by odkupić nie tylko samą ludzkość, ale i całość stworzenia. Odkąd Syn Boży stał się

${ }^{1}$ Ksiądz Ignacy Bokwa, ur. 1957, kapłan diecezji radomskiej, profesor nauk teologicznych, profesor zwyczajny na Wydziale Teologicznym Uniwersytetu Kardynała Stefana Wyszyńskiego w Warszawie. Pola badań: teologia systematyczna, teologia kultury i teologia religii. Autor i redaktor 11 książek oraz ponad 115 artykułów naukowych.

2 Por. H. Denzinger, Enchiridion symbolorum, definitionum et declarationum de rebus fidei et morum, P. Hünermann, H. Hoping (Hg.), Verlag Herder, Freiburg im Breisgau-Basel-Rom-Wien ${ }^{39}$ 2001, nr 300-303: Konzil von Chalkedon. 
człowiekiem, odtąd Bóg nosi nowe imię, które wolno traktować jako objawione i powierzone. W ten sposób imię Jezus staje się imieniem własnym Boga, esencją wcielenia, epifanii i odkupienia człowieka.

Imię Jezus ma również podstawowe znaczenie w soteriologii: I nie ma $w$ żadnym innym zbawienia, gdyż nie dano ludziom pod niebem żadnego innego imienia, w którym moglibyśmy być zbawieni (Dz 4,12). Zasadą zbawienia jest uznanie Jezusa z Nazaretu za Bożego Syna i Pomazańca, objawiającego całą prawdę o Bogu i Jego zamiarze zbawienia człowieka. Soteriologia podkreśla, że zbawienie dokonało się w ludzkiej naturze Jezusa Chrystusa doskonale zjednoczonej z Jego Boską naturą. W tym sensie człowieczeństwo wcielonego Syna Bożego jest przyczyną sprawczą naszego zbawienia. Wynika więc stąd, że pogłębiona refleksja nad imieniem Jezus prowadzi w teologii systematycznej do podjęcia wysiłku ponownego odkrycia człowieczeństwa Jezusa Chrystusa. Próby te uprawniają do wniosku, że imię Jezus oznacza program życia i działalności wcielonego Syna Bożego, który bez wątpienia ma zdecydowany wymiar soteriologiczny.

Przy tak zarysowanym problemie warto spojrzeć w kierunku współczesnej teologii systematycznej i poszukać w niej propozycji, które mogą posłużyć pogłębieniu teologii imienia Jezus - w znaczeniu powyżej naszkicowanym. Chodzi przede wszystkim o poszerzenie refleksji nad człowieczeństwem Jezusa Chrystusa jako narzędziem Bożego zbawienia i o świadomość obecności zbawienia w codziennym życiu człowieka wierzącego. Zatrzymując się nad tym zagadnieniami, jednocześnie pogłębiamy teologię imienia Jezus. Wydaje się, że istotne impulsy w tym względzie mogą pochodzić od teologii Karla Rahnera oraz ze strony teologii narracyjnej. Należy przy tym dodać, że prezentacja obu typów systematycznej refleksji teologicznej z oczywistych względów nie wyczerpuje zagadnienie, a niniejsze opracowanie ma charakter przyczynkarski.

W teologii katolickiej XX wieku mało który teolog uczynił tak wiele dla systematycznego wbudowania antropologii $\mathrm{w}$ struktury chrystologii i soteriologii jak niemiecki jezuita, Karl Rahner (1904-1984). Już w jednym ze swoich pierwszych opracowań zdecydowanie teologicznych, a poświęconych zagadnieniom chrystologicznym ${ }^{3}$, stwierdził on, że przeciętny chrześcijanin jest ,anonimowym monofizytą". Oznacza to, że choć formalnie wyznaje on wiarę w pełne człowieczeństwo Jezusa Chrystusa, to jednak faktycznie postrzega on ludzką naturę wcielonego Słowa jako zdominowaną przez Jego Bóstwo. Stąd rodził się Rahnerowski postulat dowartościowania człowieczeństwa Jezusa Chrystusa poprzez odkrycie go na nowo. Jego teologia i chrystologia transcendentalna stanowią udaną próbę włączenia antropologii do refleksji teologicznej jako jej integralnej

${ }^{3}$ Por. K. Rahner, Probleme der Christologie von heute, w: tenże, Schriften zur Theologie, Bd. I, Benziger Verlag, Einsiedeln 1954, s. 169-222. 
części. Jest to uzasadnienie dla zajmowania się teologią Karla Rahnera w kontekście systematycznej refleksji nad imieniem Jezus.

Druga część niniejszego opracowania zostanie poświęcona teologii narracyjnej. Pozostaje ona w ścisłym związku z teologiczną myślą Karla Rahnera, choć, w odróżnieniu od niej, zajmuje się ona przede wszystkim praktycznymi aspektami przybliżenia postaci Jezusa z Nazaretu przeciętnemu człowiekowi współczesnemu, żyjącemu w warunkach postępującej ateizacji i sekularyzacji. Teologia narracyjna nie jest pozbawiona elementu teoretycznego, ale jej zadaniem jest próba ukazania, że także dziś można z powodzeniem ukazać Jezusa Chrystusa jako Dawcę zbawienia, angażując egzystencjalnie człowieka w życiowy związek $\mathrm{z}$ wcielonym Synem Bożym.

\section{Karl Rahner: Odkrycie znaczenia antropologii dla chrystologii i całości teologii}

\subsection{Czlowiek w wymiarze teologicznym}

Jeden z największych katolickich teologów XX wieku, Karl Rahner, proponuje jednoznacznie teologiczną wizję człowieka ${ }^{4}$. To, co człowiek wie o sobie „naturalnie” - a więc niezależnie od historycznego objawienia Bożego, powinno zostać prześwietlone światłem Bożego Objawienia. Oznacza to więc, że koncepcja teologiczna staje się najważniejszym fundamentem antropologii ${ }^{5}$. Światło wiary jest tu najważniejsze, gdyż przewyższa ono światło naturalnego rozumu, czyniąc go swoim integralnym elementem. Przesłanie wiary staje się najwyższą, nienormowaną normą istotnej wypowiedzi o człowieku, także wtedy, kiedy zostanie ono poddane egzystencjalnemu oglądowi tegoż człowieka, następującemu w świetle jego doświadczenia samego siebie. W warunkach historycznej i bytowej zależności oraz niewystarczalności człowieka dokonuje się teologiczna interpretacja jego istoty ${ }^{6}$. W świetle Bożego Objawienia człowiek może zostać pojęty jako nadprzyrodzony egzystencjał (übernatürliches Existential) ${ }^{7}$, co w języku teologii Rahnera, posługującego się w tym przypadku filozoficzną terminologią Martina Heideggera, oznacza, że tenże człowiek jest z natury istotą powołaną do łaski, do nadprzyrodzoności i przez tę rzeczywistość ostatecznie określoną. Ten sam człowiek żyje i pojmuje siebie w realnym świecie doświadczalnej rzeczy-

${ }^{4}$ Por. K. Rahner, Anthropologie (Theologische), w: Lexikon für Theologie und Kirche, Bd. I, red. J. Hofer, K. Rahner, Verlag Herder Freiburg in Breisgau, Freiburg/Br. 1986, kol. 623.

${ }_{5}^{5}$ Por. K. Góźdź, Teologia człowieka. Z najnowszej antropologii niemieckiej, Wydawnictwo KUL, Lublin 2006, s. 226-256: „Koncepcja teologiczna fundamentem antropologii”.

${ }^{6}$ Por. K. Rahner, Anthropologie (Theologische), kol. 623.

7 Por. H. Verweyen, Wie wird ein Existential übernatürlich? Zu einem Grundproblem der Anthropologie K. Rahners, „Trierer Theologische Zeitschrift“ 95(1986) z. 2, s. 115-131. 
wistości. Tym samym początek wszelkiej refleksji intelektualnej tkwi w historii. W tej historii przychodzi Boże Objawienie, w historii urzeczywistnia się też akt wiary.

W tej perspektywie należy rozumieć podstawową tezę Rahnerowskiej antropologii teologicznej: „Wyznający chrześcijańską wiarę człowiek pojmuje siebie - mimo i w swojej stworzoności i grzeszności - jako ten, do którego zwrócił się w historii Bóg, i to przy pomocy Słowa absolutnego, wolnego, a więc łaskawego samootwarcia Boga w Jego jak najbardziej własnym życiu"8. Otwierającemu się Bogu odpowiada otwarta struktura ludzkiego bytu, czyli jego duchowość9.

Niemiecki teolog postulował, by wszystkie dogmaty odczytywać jako stwierdzenia teologicznej antropologii. Człowiek jest bowiem punktem przecięcia Bożego Objawienia i historycznego doświadczenia samego siebie. W świetle radykalnej interpretacji istoty ludzkiego bytu staje się możliwym ustalenie głównych dymensji człowieka. Podstawową jest jego stworzoność, pozwalająca rozróżnić między naturą a łaską. Karl Rahner daje pierwszeństwo indywidualnemu bytowi człowieka przed jego wymiarem społecznym. W swej najgłębszej istocie człowiek jest duchem w świecie ${ }^{10}$ i słuchaczem Bożego słowa ${ }^{11}$, adresatem Jego Objawienia, możliwego do rozpoznania przez naturalny umysł. Boże Objawienie jest tak radykalnym samootwarciem się Boga, że człowiek nie jest w stanie zareagować na nie inaczej niż tylko w postawie absolutnego, a więc miłującego posłuszeństwa wiary. Człowiek jest jednak zdolny także do niewiary, a więc do grzesznego zamknięcia się na nieskończoną otwartość Boga w Jego samoudzieleniu się. Człowiek w żaden sposób nie jest w stanie zaprzeczyć swojej podstawowej tożsamości bytowej, jaką jest bycie potentia oboedientialis - aktywną możnością okazania Bogu posłuszeństwa wiary i miłości jako Jego nadprzyrodzonej łasce ${ }^{12}$. Ta cecha potencji posłuszeństwa względem Boga staje się dla nie-

${ }^{8}$ K. Rahner, Anthropologie (Theologische), kol. 624. Znamiennym jest fakt, że hasło: Antropologia - teologiczna, C.: Antropologia systematyczna, zamieszczone w Encyklopedii Katolickiej $K U L$, rozpoczyna się od pytania o genezę człowieka. Oznacza to zgoła inne podejście do tematu. A Rahner zaczynał pisać swoje pierwsze dzieła już przed II wojną światową (por. W. Granat, $A n$ tropologia - teologiczna, cz.: Antropologia systematyczna, w: Encyklopedia Katolicka, t. I, red. F. Gryglewicz, R. Łukaszyk, Z. Sułowski, Wydawnictwo Towarzystwa Naukowego KUL, Lublin 1973, kol. 698-702.

9 „Człowiek jest wiec - według Rahnera - konkretnym bytem, który ma otwartą duchowość. Jest też bytem, który odznacza się wolnością. W tej wolności człowiek stoi wobec wolnego Boga, który może się objawić w historii przez słowo. Jest to najpełniejsza aktualizacja historii. Człowiek jest tym, który jest w swojej historii nasłuchującym Słowa Bożego" (K. Góźdź, Teologia człowieka, s. 241).

${ }^{10}$ Por. K. Rahner, Geist in Welt. Zur Metaphysik der endlichen Erkenntnis bei Thomas von Aquin, Verlag Felizian Rauch, Innsbruck 1939.

${ }^{11}$ Por. K. Rahner, Hörer des Wortes. Zur Grundlegung einer Religionsphilosophie, Verlag Kösel-Pustet, München 1941.

${ }^{12}$ Por. K. Góźdź, Teologia człowieka, s. 251-252: „Samoudzielenie się Boga”. 
mieckiego jezuity punktem wyjścia dla zbudowania teologicznego pojęcia tego wszystkiego, co kryje się pod pojęciem ludzkiej duchowości, w której mieszczą się takie przymioty jak transcendencja, wolność czy wieczna trwałość w postaci nieśmiertelności ludzkiej osobowości.

Historyczność możności wsłuchiwania się w Boże Objawienie w postaci wcielonego Słowa pozwala spojrzeć na ludzką historyczność jako na wypowiedź typu teologicznego. Dopiero wtedy można w uzasadniony sposób traktować o ludzkim zakorzenieniu w stworzony przez Boga świat, o jego cielesności, o ludzkiej płciowości jako istotnym wymiarze życia społecznego, urzeczywistniającego się w rodzinie, narodzie, państwie i Kościele. Dopiero wtedy, gdy uwzględni się teologiczny punkt wyjścia - i dojścia - człowieka, sensownym staje się mowa o agonalności jego bycia człowiekiem tu i teraz, o historycznym uwarunkowaniu i niemożliwej do pokonania kondycji „wrzucenia w istnienie”.

\subsection{Czlowiek odczytany w świetle Jezusa Chrystusa}

Relacja pomiędzy chrystologią a teologiczną antropologią jest dla Rahnera egzystencjalnym związkiem między człowiekiem a Jezusem Chrystusem, jego Zbawicielem ${ }^{13}$. Niebezpieczną iluzją teologii - zdaniem Rahnera - było bezrefleksyjne podejście do znaczenia pojęcia człowieka, gdy przychodziło powiedzieć, że Jezus Chrystus był prawdziwym człowiekiem. Wyłączne odwołanie do naszego doświadczenia bycia człowiekiem, pozbawionego koniecznego teologicznego horyzontu i teologicznych pryncypiów, prowadziło do niebezpiecznego zawężenia chrystologii. Co najwyżej można było bowiem stwierdzić, czego z naszej ludzkiej kondycji nie znajdziemy u Jezusa Chrystusa, a więc grzeszności. Z tej racji mowa o Jezusie Chrystusie jako człowieku na „idealny sposób”, jako przykładzie dla człowieka i idealnym modelu teologicznej antropologii trafiała właściwie w pustkę. Teologiczna antropologia może formułować swoje podstawowe twierdzenia o człowieku (na przykład zmartwychwstanie, przebóstwiająca łaska Boża) dopiero wtedy, gdy zaistnieje chrystologia. Ta zaś bazuje na przekonaniu, że człowieczeństwo Boskiego Logosu nie jest jedynie bezwiednym instrumentem, przy pomocy którego niewidzialny Bóg staje się zauważalny w świecie, lecz to człowieczeństwo staje się tym, kim jest sam Bóg - pozostając ciągle rzeczywistym, prawdziwym człowieczeństwem. Dzieje się tak wtedy, kiedy Bóg dokonuje kenozy, przechodząc do wymiaru tego, co inne niż On sam, co nie-boskie. Tym samym, mówi Rahner, dochodzimy do tego, czym w swojej najgłębszej istocie jest człowiek: możliwym Innym, gdy Bóg zechce dokonać kenozy i zrezy-

13 Por. I. Bokwa, Christologie als Anfang und Ende der Anthropologie. Über das gegenseitige Verhältnis zwischen Christologie und Anthropologiebei Karl Rahner, Verlag Peter Lang, Frankfurt am Main - Bern - New York - Paris 1990. 
gnować ze swego Boskiego sposobu bycia, nie rezygnując jednak ze swej istoty. Tym Innym dla Boga staje się człowiek jako możliwy brat Jezusa Chrystusa. Ze swej natury bowiem człowiek to potentia oboedientialis dla unii hipostatycznej i dla łaski Jezusa Chrystusa ${ }^{14}$.

W oparciu o unię hipostatyczną Rahner formułuje jedno ze swoich najbardziej znanych twierdzeń, określających formalnie związek chrystologii i antropologii ${ }^{15}$, zaś w istocie rzeczy mówiący o nierozerwalnym związku człowieka z Bogiem: „W odwołaniu do Boga i do człowieka chrystologia jawi się jako najbardziej radykalne, przewyższające wszystko powtórzenie teologicznej antropologii" ${ }^{16}$. Tym samym Karl Rahner domaga się dowartościowania realnej historii, w której żyje i którą tworzy człowiek, adresat Bożego zbawienia.

\subsection{Karla Rahnera wkład do refleksji nad imieniem Jezus}

Już na wstępie krótkiej prezentacji teologii Karla Rahnera w aspekcie jego antropologii i chrystologii należało się pogodzić z faktem, że nie jest to prosta kontynuacja czy pogłębienie refleksji nad imieniem Jezus. Tak mogą uczynić biblistyka, patrologia, liturgika czy teologia duchowości, które są predestynowane do refleksji nad imieniem Jezus. Niemiecki teolog zajął się zagadnieniem o wiele szerszym, a stanowiącym platformę dla refleksji nad teologicznym wymiarem imienia Jezus, mianowicie miejsce antropologii (teologicznej) w teologii dogmatycznej (systematycznej). Ktoś, kto jedynie naskórkowo zetknął się z teologiczną myślą Karla Rahnera, może dojść do przedwczesnego wniosku, że ten wielki zwolennik metody transcendentalnej w teologii ${ }^{17}$, wychodząc od człowieka, włączył się tym samym w nurt myśli humanistycznej, łatwo zapominającej o Bogu, za to gloryfikującej człowieka. Radykalna myśl humanistyczna zawierała w sobie niekiedy ukrytą bądź jawną tendencję do ateizmu, przeciwstawiającego sobie radykalnie Boga i człowieka. Rahner zaczyna wprawdzie od człowieka i jego doświadczenia, a nawet przed-doświadczenia, ale po to, by ponad wszelką wątpliwość wykazać, że bez Boga człowiek nie istnieje, co więcej, jest nie do pomyślenia. Wyrażone skompli-

${ }^{14}$ Por. K. Rahner, Potentia oboedientialis, w: Sacramentum Mundi, Bd. III, red. K. Rahner, A. Darlap, Freiburg/Br. 1969, kol. 1245-1249.

${ }_{15}$ Relacja chrystologii i antropologii zajmowała wielu teologów. Wystarczy tu wskazać choćby na Karla Bartha (por. E.H. Friedmann, Christologie und Anthropologie. Methode und Bedeutung der Lehre vom Menschen in der Theologie Karl Barths, Vier-Türme-Verlag, Münsterschwarzach 1972) czy Waltera Kaspera (por. Z. Joha, Christologie und Anthropologie. Eine Verhältnisbestimmung unter besonderer Berücksichtigung des theologischen Denkens Walter Kaspers, Verlag Herder, Freiburg-Basel-Wien 1992).

${ }^{16}$ K. Rahner, Anthropologie (Theologische), kol. 626.

17 Por. N. Knoepffler, Der Begriff ,,transzendental” bei Karl Rahner. Zur Frage seiner Kantischen Herkunft, Tyrolia - Verlag, Innsbruck - Wien 1993. 
kowanym językiem filozoficznej analizy „Summy teologicznej” świętego Tomasza z Akwinu, czytanego i interpretowanego przez pryzmat transcendentalnego tomizmu Josepha Maréchala SJ oraz egzystencjalnej filozofii Martina Heideggera, przekonanie jest jedno: Każdym aktem swojego istnienia, chcenia i myślenia człowiek potwierdza istnienie Boga, od którego pochodzi i ku któremu zmierza ${ }^{18}$. Użycie języka filozoficznego, nawet jeśli jest on związany z konkretną epoką i kulturą, było głęboko przemyślane i celowe. Rahner nie zamierzał bowiem ograniczać się jedynie do ściśle określonej grupy wyznaniowej, do ludzi już przekonanych, ale myślał o wiele szerzej - o wszystkich ludziach nierezygnujących z użycia własnego rozumu, ze zdolności i radości myślenia.

Tym, co Karl Rahner przekazuje naszym czasom, filozofom i teologom borykającym się z ponowoczesnym rozwodnieniem tak filozofii, jak i teologii ${ }^{19}$, jest zadanie tak pilne, jak odpowiedzialne i trudne: wyrazić w języku naszej epoki podstawową prawdę o zasadności bycia chrześcijaninem, o pięknie człowieczeństwa opartego na Bogu, a zarazem o bezsensie i tragedii ateizmu. Podwaliny swojej teologii Rahner tworzył w dobie wojującego ateizmu, który tak na płaszczyźnie teorii, jak i praktyki, wszelkimi możliwymi sposobami starał się wykazać, że Bóg to chimera, wytwór chorej ludzkiej wyobraźni, co więcej - wyrafinowany wróg człowieka, czyhający na jego wielkość i godność. Całość teologicznej myśli i działalności Karla Rahnera służyła wykazaniu błędności i szkodliwości takiego myślenia i takiej postawy życiowej. Zarówno sam człowiek, jak i jego refleksja o otaczającym go świecie, są możliwe, gdyż istnieje miłujący Bóg, pragnący udzielić się na zewnątrz, stać się darem dla swojego stworzenia ${ }^{20}$. Warto wczytać się w Rahnerowską teorię symbolu urzeczywistniającego, opracowaną na bazie chrystologii ${ }^{21}$. Człowieczeństwo Jezusa Chrystusa nie jest przypadkową

${ }^{18}$ Por. K. Rahner, Geist in Welt.

19 Por. I. Bokwa, Teologia w warunkach nowoczesności i ponowoczesności, Wydawnictwo Diecezjalne w Sandomierzu, Sandomierz 2010.

${ }^{20}$ Opierając się na artykule Theologie und Anthropologie, zamieszczonym przez K. Rahnera w VIII tomie jego Schriften zur Theologie, Benziger Verlag, Einsiedeln 1967, s. 43-65, K. Góźdź formułuje trzy zasadnicze aksjomaty korelacji teologii i antropologii: ,-- Antropologia teologiczna pyta w sposób aprioryczno-transcendentalny o istotę człowieka, o jego transcendentalną strukturę bytu oraz o strukturę doświadczenia, które zakłada i warunkuje jego historyczny byt. - Antropologia teologiczna ma swój punkt wyjścia w pierwotnej wypowiedzi teologicznej. Jest to refleksja nad człowiekiem, która bazuje na Objawieniu Bożym w Jezusie Chrystusie. Chodzi o to, żeby nie stwarzać zależności od antropologii świeckiej. - Antropologia teologiczna w swoim ukierunkowaniu antropocentrycznym nie jest żadnym przeciwieństwem teologicznej teocentryki. Antropocentryka i teocentryka teologii tworzą dwie perspektywy jednej i tej samej rzeczywistości, które wzajemnie się warunkują i uzupełniają" (K. Góźdź, Teologia człowieka, s. 229). Por. także: J.B. Metz, Antropocentrismo cristiano. Studio sulla mentalità di Tommaso d'Aquino, tł. A. Audusio, Borla Editore Torino, Torino 1969.

${ }^{21}$ Por. K. Rahner, Zur Theologie des Symbols, w: K. Rahner, Schriften zur Theologie, t. IV, Benziger Verlag, Einsiedeln 1959, s. 275-311. 
„liberią”, przyodziewaną przez niewidzialne Słowo, Boży Logos, lecz rzeczywistością ontycznie tworzoną przez Boga jako Jego zewnętrzny wyraz. Dopiero wtedy sensownie można powiedzieć, że człowiek jest pytaniem, a Jezus Chrystus odpowiedzią, że chrystologia jest końcem i początkiem antropologii, że człowiek jest poszukującą chrystologią, otwartą na zbawienie w Jezusie Chrystusie, żyjącą memoria Christi ${ }^{22}$.

Dzieło Karla Rahnera jest jednoznacznie teologią: „Podstawowym źródłem teologicznej interpretacji sensu świata, człowieka i historii jest Bóg. Jest On rozumiany jako niestworzona łaska Jego samoudzielania się (i to jest święta tajemnica), w którym to samoudzieleniu staje się On nam bliski i stanowi centrum naszej egzystencji. Jako łaska Chrystusa kulminuje to pełne łaski historiozbawcze samoobjawienie się trynitarnego Boga w historycznej postaci Jezusa z Nazaretu, który jest eschatologicznym apogeum samoobjawienia się Boga i Jego nieodwracalnym ukazaniem się wewnątrz historii ludzkości" ${ }^{23}$. W kluczu teocentrycznym zawiera się kod chrystologiczny i antropologiczno-teologiczny. Uwzględniając te założenia, można właściwie docenić doniosłość Rahnerowskiej chrystologii transcendentalnej, pytającej (paradoksalnie) o warunki możliwości poznania przez człowieka Jezusa Chrystusa i przyjęcia Go jako Zbawcy absolutnego. Takie postawienie problemu służy pogłębieniu egzystencjalnej relacji człowieka z Jezusem Chrystusem, zaś samą antropologię czyni integralnym momentem teologii systematycznej.

\section{Teologia narracyjna a systematyczna refleksja nad imieniem Jezus}

\subsection{Podstawowe elementy i rodzaje teologii narracyjnej}

Związek teologii narracyjnej, rozumianej leksykalnie, z refleksją nad imieniem Jezus wydaje się odległy i trudny do ustalenia. Tak jednak nie jest. O ile teologia Karla Rahnera ukazała szerokie tło zanurzonej w teologii antropologii, dowartościowującej człowieczeństwo Jezusa Chrystusa, o tyle teologia narracyjna jest próbą wskazania dróg przybliżenia postaci Jezusa z Nazaretu i Jego misji zbawczej potencjalnie wielkiej liczbie ludzi, zwłaszcza tych pozostających $z$ dala od Boga i wiary. Swoją nazwę teologia narracyjna wywodzi od łacińskiego czasownika narrare (opowiadać). Jest to nowoczesna próba odnowienia teologii chrześcijańskiej jako teologii religii historycznej, która nie tylko ma coś do przekazania w postaci pisemnie utrwalonych reguł wiary, ale ma także wydarzenia, które warto na nowo opowiedzieć. Wyzwalając się od abstrakcyjnych stwierdzeń

${ }^{22}$ Por. I. Bokwa, Wprowadzenie do teologii Karla Rahnera, Wydawnictwo Diecezji Tarnowskiej BIBLOS, Tarnów 1996, s. 108-112.

${ }^{23}$ K. Góźdź, Teologia człowieka, s. 253-254. 
doktrynalnych, teologia narracyjna odnajduje swoją duchową ojczyznę w biblijnych i innych religijnych opowiadaniach. Teologia narracyjna zapobiega wszelkim dążeniom do oderwania teologii od życia i kultu, potrzeba jej jednak krytycznych zasad umożliwiających ustalenie znaczenia i prawdy. Wśród chrześcijan wschodnich narracyjny wątek w teologii ocalał w liturgii i ikonach.

Teologia narracyjna ${ }^{24} \mathrm{w}$ liczbie pojedynczej nie istnieje, jako że sensownie można mówić jedynie o wielości niekiedy zasadniczo różniących się między sobą, mających charakter szkiców opracowań zaczątkowych. Prekursorami teologii narracyjnej byli dwaj niemieccy teologowie - Johann Baptist Metz i Harald Weinrich. Ich szkice teologii narracyjnej ukazują jej zasadniczo różne możliwości.

Zainteresowanie Johanna Baptisty Metza teologią narracyjną wyrasta z jego recepcji Szkoły Frankfurckiej w ramach projektu teologii politycznej. Historyczność myślenia czyni niemożliwą do przyjęcia ahistoryczną koncepcję rozumu. W perspektywie teorii krytycznej ukształtował on pojęcie historii jako historii cierpienia. Wyzute z zainteresowań i emocji poznanie mogłoby być jedynie owocem niedokonującego wyborów rozumu, a taka wizja okazuje się iluzją. Ludzki rozum jest do głębi przesycony wolnością i skłonnością do humanizacji, wskutek czego staje się on memoria passionis, zatrzymując w sobie niespełnione oczekiwania szczęścia ofiar historii. Takie pojęcie rozumu należy traktować jako krytykę wywodzącej się z tradycji oświeceniowej jednostronnej koncepcji postępu. Wspominający rozum zawiera w sobie, jeśli ujmiemy go w ramach myśli chrześcijańskiej, wymiar soteriologiczny: w ludzkiej anamnezie zmarłych zawiera się protest przeciwko byciu umarłymi umarłych. Pamięć ta zmierza ku memoria passionis, mortis et resurrectionis Jesu Christi oraz Jego obietnicy dopełnienia historii. Zbawczy czyn Jezusa Chrystusa stanowi rodzaj „niebezpiecznego doświadczenia”, jako że porusza on wiarę, ludzką działalność i wynikające z niej struktury życia. Kościół powstał jako wezwanie do pamięci, jest miejscem urzeczywistniania się tego wspomnienia. Teologia fundamentalna określa go mianem „wspólnoty wspominania i opowiadania”. Memoria Jesu Christi stanowi „antycypujące wspomnienie” i kieruje ku nie do końca wyczerpanemu jeszcze potencjałowi obietnicy. Kościół nie jest ograniczony ani swoją przeszłością, ani przyszłością: dzięki temu w jego współczesności staje się czytelna jego „narratywna struktura głębi”, na ile złożony „czas opowiadania” uobecnia rzeczywistość tego, o czym się opowiada. W żydowsko-chrześcijańskim opowiadaniu przeszłość i przyszłość opowiadania zostają urzeczywistnione w sposobach wspominania i nadziei. Takie eschatologiczne opowiadanie nie jest koniecznie tradycyjne, jako że roz-

${ }^{24}$ Por. K. Wenzel, Narrative Theologie, w: Lexikon für Theologie und Kirche, red. W. Kasper, t. 7, Verlag Herder, Freiburg - Basel - Rom - Wien 1998, kol. 640-643. 
wija ono zdolność obrony przeciwko ustalonym strukturom i dogmatycznym stwardnieniom, czerpiąc z żywego opowiadania. Anamnetyczny wymiar opowiadania nie bazuje w pierwszym rzędzie na przekazaniu wiadomości, lecz stanowi praktyczne przełożenie $\mathrm{w}$ dynamiczny proces naśladowania i nawrócenia. Integracja z motywem naśladowania wskazuje na bliskość względem koncepcji teologii wyzwolenia, która pojęcie i praktykę naśladowania uwalnia od indywidualistycznych i statycznych zwężeń (imitatio), otwierając ją na „królewską” praktykę królestwa Bożego na ziemi.

Oprócz tej bardziej społecznej wizji teologii narracyjnej istnieje jej wersja bardziej zindywidualizowana. W twórczości Haralda Weinricha daje o sobie znać kryterium narratywnego przejęcia się czy też historycznej prawdy, która ma posłużyć rehabilitacji mądrości jako pojęcia opisującego narratywnie przekazane doświadczenie życiowe. Rzeczywistość narratywna znajduje swój ideał w opowiadaniu ustnym, uznanym za ginące. Odwołanie się do dialogicznego ,ja”, istotnego dla koncepcji Martina Bubera i jego mistagogicznego przyswojenia sobie opowiadająco-przekazującej tradycji chasydyzmu, pozwala odkryć teologiczno-terapeutyczny potencjał opowiadania. Sięgające początków historii Kościoła katechetycznego i religijno-pedagogicznego zastosowanie opowiadania nie tylko zawiera protest przeciwko sztywnej teologicznej systematyce, lecz pokazuje, iż życiowo-historyczne przyswojenie chrześcijańskiej tradycji może stanowić centrum projektu symboliczno-opowiadającej teologii ${ }^{25}$. W aspekcie praktyczno-teologicznym istnieje możliwość stworzenia teologicznej estetyki w nawiązaniu do warstwy narracyjnej ${ }^{26}$.

Gary L. Comstock rozróżnił pomiędzy czystymi narratywistami a tymi, którzy przyznają pewne miejsce refleksji systematycznej ${ }^{27}$. W pierwszej grupie jako jej prominentny przedstawiciel znalazł się Karl Barth, radykalnie zwracający się przeciwko jakiejkolwiek interpretacji i analizie przesłania Objawienia Bożego (historyczno-krytycznej, egzystencjalno-ontologicznej, hermeneutycznej czy transcendentalno-ontologicznej). O jakości opowiadania rozstrzyga jedynie literalna zawartość, polegającej na sobie samej biblijnej historii. Każdy teologiczny dyskurs drugiego porządku (stopnia) dotyczący Objawienia zagraża utratą kontaktu z nim. Pomimo różności gatunków biblijny tekst można traktować jako jedno opowiadanie, którego klucz interpretacyjny leży w nim samym - w opowiadaniu o ukrzyżowaniu i zmartwychwstaniu Jezusa Chrystusa. Dochodzi przy tym do odwrócenia tradycyjnego schematu recepcji: To nie czytelnik przyswaja

${ }^{25}$ Por. G. Baudler, Einführung in die symbolisch-erzählende Theologie. Der Messias Jesus als Zentrum der christlichen Glaubenssymbole, Verlag Ferdinand Schöningh, Paderborn 1982.

${ }^{26}$ Por. A. Grözinger, Erzählen und Handeln. Studien zu einer trinitarischen Grundlegung der praktischen Theologie, Chr. Kaiser Verlag, München 1989.

${ }^{27}$ Por. G.L. Comstock, Two Types of Narrative Theology, „Journal of the American Academy of Religion" 55(1987), s. 687-717. 
sobie biblijne opowiadanie, lecz to ono przyswaja sobie czytelnika. W swoim roszczeniu ujęcia całej ludzkiej rzeczywistości opowiadanie biblijne potwierdza, iż jest rzeczywiście opowiadaniem jednego Boga.

Do drugiej grupy został zaliczony Nicholas Lash, pozostający pod wpływem Johna Henry'ego Newmana i Karla Rahnera, twierdzący, że jedność i wewnętrzny porządek Objawienia nie są możliwe do rozpoznania na drodze systematyczno-teologicznej spekulacji, lecz w opowiadaniu i przez opowiadanie wiary, przy czym opowiadanie oznacza złożony proces przyswajającej i tym samym potwierdzającej swoją żywotność tradycji. Porządkujące funkcje opowiadania są dynamiczne, jako że transformacja tradycji następuje w akcie przyswajania, natomiast pośredniczenie pomiędzy biograficzną, historyczną i kulturową partykularnością aktu przyswajania z jednej strony dzieje się w stosunku do możliwości przełożenia chrześcijańskiego opowiadania w ciągu historii i ponad kulturowymi granicami z drugiej strony. Dynamika po chrześcijańsku pojmowanej historii urzeczywistnia się przede wszystkim w relatywnej pluralności jej konkretyzacji, co uprawnia do stwierdzenia synchronicznej i diachronicznej interpretacyjnej otwartości tejże historii. W takiej otwartości chrześcijańskie opowiadanie pozostaje w związku z Credo, które w swej istocie jest skróconym, skondensowanym opowiadaniem. Podobnie jak dogmaty, pełni ono funkcję korekcyjną w stosunku do opowiadania, które z kolei jest nakierowane na dogmat - Credo jawi się tu głównie w swoim wymiarze treściowym. Lash pojmuje teologię narracyjną $\mathrm{w}$ ramach tradycji teologii negatywnej: teologia narracyjna w sposób epicki urzeczywistnia wgląd w konieczność Bożej mowy w obliczu niemożności wyrażenia tajemnicy Boga ${ }^{28}$.

Wychodząc poza ramy powyższego dychotomicznego podziału, Sallie McFague odkrywa wewnętrzne powiązanie opowiadania z metaforą ${ }^{29}$, co omawia również Paul Ricoeur ${ }^{30}$. Z opierającej się na poglądach Paula Tillicha, zdecydowanie reformowanej perspektywy, McFague postrzega historię chrześcijańskiego dyskursu, zdynamizowanego przez metaforę, pojmując ją jako pojęcie przeciwne w stosunku do „katolickiego”, kultyczno-kapłańskiego rozumienia sakramentu. Ricoeur rozumie metaforę jako „semantyczną innowację”, którą McFague radykalizuje w kierunku religijnym i ideologiczno-krytycznym, zmierzając ku krytyce niejako dyrygujących Bożą mową dogmatów. Również one są skazane na prorocko-otwarty, prowizoryczny, pośredni, ikonoklastyczno-metaforyczny proces chrześcijańskiej mowy o Bogu.

28 Por. N. Lash, Theology on the Way to Emmaus, SCM Press, London 1986.

29 Por. S. McFague, Metaphorical Theology, SCM Press, London 1983.

${ }^{30}$ Por. P. Ricoeur, Zeit und Erzählung, t. 1-3, thum. A. Knop, Verlag Fink, München 1988-1991; tenże, Le sujet convoquè, „Revue de l'Institut Catholique” 28(1988), s. 83-99. 


\subsection{Dogmat i symbol jako środki przybliżenia Osoby i zbawczej misji Jezusa}

Teologia narracyjna zwraca uwagę na fakt, iż uobecnienie zabitego Jezusa jako żywego Mesjasza dla konkretnego człowieka czy też danej ludzkiej wspólnoty nie może następować w oparciu o rozumową argumentację czy historyczną dokumentację, gdyż pojawia się problem przerzucenia mostu pomiędzy tamtymi historycznymi wydarzeniami a obecną sytuacją. Można to uczynić nie tyle siłami intelektu, ile bardziej przy wykorzystaniu wszystkich władz człowieka, a więc także jego uczuć, wyobraźni i fantazji. Będzie to całościowe przybliżenie się do znajdującego się w centrum fundamentu wiary. Kiedy chodzi o „widzenie" ukrzyżowanego Mesjasza, pomocna staje się nie tyle dyskursywna logika, ile raczej „logika reprezentatywna”, posługująca się metodą narracji $i^{31}$.

Zarówno Stary, jak i Nowy Testament posługują się metodą narracji, a nawet można je określić mianem struktur narracyjnych ${ }^{32}$. Pomiędzy biografią odbiorców Dobrej Nowiny o zabitym i zmartwychwstałym Mesjaszu a przesłaniem wiary, które jest im przekazywane jako narracja, istnieje ścisła korelacja: oba te bieguny muszą zostać wyrażone w postaci „,reprezentatywnych symboli” - każdorazowa sytuacja osobistego doświadczenia adresata ma znaleźć odniesienie do rozumianego jako całość życia Jezusa Chrystusa, natomiast każdy element przekazu wiary ma swój ostateczny kontekst w śmierci i zmartwychwstaniu Jezusa Chrystusa jako fundamencie chrześcijańskiej wiary.

Choć teologia jest w pierwszym rzędzie racjonalną refleksją nad treściami Objawienia Bożego, którego szczytem jest Jezus Chrystus, to może być ona rozumiana również jako nauka o chrześcijańskich symbolach. Świat symboli chrześcijańskiej tradycji wiary powinien otworzyć się na racjonalną refleksję, aby móc zrozumieć ich wewnętrzne powiązania, poznać historię ich powstania oraz bliskość pewnych symboli w stosunku do określonych sytuacji życiowych. Życie chrześcijanina oraz tradycja wiary, pośród wielu innych, mają także ten wymiar, który jest dostępny zarówno racjonalnej argumentacji, jak i fenomenologicznemu opisowi.

W pierwotnym Kościele wyznanie wiary było określane mianem symbolu i oznaczało znak rozpoznawczy, porównywalny z flagą narodową, dzięki której dany statek pozwala rozpoznać swoją przynależność narodową. Ta możność rozpoznania jest, oprócz innych znaczeń i wymiarów, całościowym, także emocjonalnym aktem, „symbolem reprezentatywnym”. Wyrażona w języku dogma-

${ }^{31}$ Por. G. Baudler, Wahrer Gott als wahrer Mensch. Entwürfe zu einer narrativen Christologie, Verlag Kösel, München 1977, s. 12-17.

32 Por. G. Lohfink, Erzählen als Theologie. Zur sprachlichen Grundstruktur der Evangelien, „Stimmen der Zeit” 192(1974), s. 521-532, zwł. s. 522. 
tycznych formuł i symboli wiary tradycja chrześcijańska jest nie tylko rodzajem budynku, w którym spotykają się niewykluczające się nawzajem wypowiedzi, lecz zbiorem symboli, zorganizowanym wokół swojego centrum - misterium Jezusa Chrystusa jako fundamentu wiary. Teologia narracyjna podkreśla konieczność interioryzacji tego Centrum, tak, aby stało się ono wewnętrznym światem jego osobistej symboliki. Zadaniem katechezy zatem jest re-symbolizacja chrześcijańskiej tradycji, która przyjęła postać nauki, doktryny: mniej lub bardziej sztywny budynek tradycji ma więc na nowo stać się żywym światem symboli, formującym się niejako $\mathrm{z}$ wnętrza chrześcijańskiego misterium i otwartym na codzienność chrześcijańskiej egzystencji. Należy przy tym podkreślić konsekwentny chrystocentryzm tego konceptu: historycznym początkiem i wyciśniętym przezeń prawzorcem świata chrześcijańskich symboli jest Jezus z Nazaretu jako wywyższony i żyjący Mesjasz ${ }^{33}$.

Teologia, choć jest naukowym podejściem do chrześcijańskiej tradycji, nie może być jednak zredukowana do pragmatycznego wymiaru pojęcia nauki ${ }^{34}$. Należy w niej uwzględnić konkretnego, historycznego człowieka, z jego osobistą biografią, w której następuje wydarzenie zetknięcia z Ewangelią i jej przesłaniem. Żyjący w świeckiej codzienności człowiek ma szansę urzeczywistnić w swojej egzystencji ukrzyżowanego rzemieślnika Jezusa z Nazaretu jako Mesjasza tego swojego świeckiego, zwyczajnego życia. Ani subtelna, precyzyjna w swoich wywodach refleksja teologiczna, ani kościelno-sakralny autorytet ze swoją nawet unowocześnioną praktyką, nie będą nigdy w stanie zastąpić tego doświadczenia i czynu wiary. Co najwyżej mogą one pomóc temu człowiekowi w wypracowaniu własnego teologicznego poznania i własnego teologicznego języka. Jest to znacząca pomoc, zachodząca na płaszczyźnie komunikacji wiary, z której wyrasta nowy język wiary. Rodzi się on w możliwie najbardziej intensywnym, dialogicznym powiązaniu własnej biografii konkretnego człowieka i jego językowego świata $\mathrm{z}$ historią życia i wyrażonym za pomocą mowy światem ukrzyżowanego Mesjasza Jezusa. W ten sposób teologia narracyjna odkrywa na nowo znaczenie człowieka jako podmiotu i osoby, co prawda rozmontowanego i zdyskredytowanego przez ponowoczesną filozofię ${ }^{35}$, a przecież stanowiącego niezbędne centrum odkrywania i doświadczania sensu.

${ }^{33}$ Por. E. Biser, Narrativität als Weg zur Identität. Zu Georg Baudlers Entwurf einer narrativen Christologie, „Zeitschrift für Katholische Theologie” (1981) nr 1, s. 56-59.

${ }^{34}$ Tendencję tę można zauważyć np. u: H. Peukert, Wissenschaftstheorie - Handlungstheorie - Fundamentale Theologie, Patmos Verlag, Düsseldorf 1976.

35 Por. S. Kowalczyk, Filozoficzne idee postmodernizmu, Polskie Wydawnictwo Encyklopedyczne POLWEN, Radom 2004; K. Wilkoszewska, Wariacje na ponowoczesność, Wydawnictwo Universitas, Kraków 2008. 


\subsection{Czlowiek we wspólnocie Kościoła: rozmowa i opowiadanie}

Standardowe podejście do Kościoła jest podejściem traktatowym i teoretycznym ${ }^{36}$. Konieczne jest więc wypracowanie takiej symboliczno-teoretycznej interpretacji chrześcijańskiej tradycji, w której znajdzie się miejsce dla narratywno-korelatywnego ujęcia Kościoła. Kompleks tradycji związany z pojęciem Kościoła zajmuje bowiem w ramach takiego odniesienia do chrześcijańskiej tradycji szczególne miejsce.

Produktywno-kreatywne podejście do „szerokiego rowu historii” (W. Lessing), dzielącego pierwociny Kościoła i aktualną sytuację człowieka wierzącego, może prowadzić do dialogicznego powiązania współczesnego doświadczenia z przekazanym przez tradycję chrześcijańskim fundamentem wiary. Zawarte w tradycji symbole mogą uzyskać nowe znaczenie dla ludzkiego życia, w którym własne doświadczenie życia i jego historia stają przed szansą krytycznego rozpoznania ich w świetle tradycji i uzyskania nowego sensu. Historyczny dystans okazuje się nie tyle przeszkodą, ile nową możliwością dla chrześcijańskiej egzystencji wiary. Ze swej natury, jak twierdzi teologia narracyjna, Kościół stanowi drogę bądź przestrzeń, w której wytworzyła się tradycja o ukrzyżowanym Jezusie jako Mesjaszu ${ }^{37}$. W Kościele powstał też kanon Ewangelii opowiadających dziś w autentyczny sposób o Jezusie jako Chrystusie, w Kościele też jako instytucji dokonywały się starcia z duchowymi i politycznymi problemami danego czasu, co znalazło swój wyraz w sformułowanych dogmatach, będących regułami i perspektywami wiary ${ }^{38}$.

Symboliczno-narratywne podejście do rzeczywistości Kościoła zawiera w sobie nowe podejście do chrześcijańskiej tradycji: przekazane przez tę tradycję symbole wchodzą $\mathrm{w}$ relację $\mathrm{z}$ moją aktualną sytuacją życiową, co przynosi uzdrawiające i nadające mojemu życiu sens działanie. Jedyne, co mogę stwierdzić w tej sytuacji, to fakt, iż mogę osiągnąć tylko subiektywną, nie zaś obiektywną pewność co do wskazywania przez ten symbol na wykraczającą poza śmierć, ostateczną podstawę wszelkiego bytu ${ }^{39}$. Instytucjonalna posługa Kościoła jako wspólnoty towarzyszącej poszczególnym wiernym w procesie przyswajania tradycyjnych symboli w ich konkretnej, historycznej egzystencji natrafia na swoje ograniczenia. Wynika to z natury procesu przyswajania tradycyjnych symboli: następuje on bowiem przy użyciu subiektywnych władz fantazji i wczu-

${ }^{36}$ Por. W. Löser, Ekklesiologie, w: Lexikon der katholischen Dogmatik, red. W. Beinert, Freiburg - Basel - Wien 1988, s. 116-117.

37 Por. A. Napiórkowski, Bosko-ludzka wspólnota. Podstawy katolickiej eklezjologii integralnej, Wydawnictwo WAM, Kraków 2009.

${ }^{38}$ Por. G. Baudler, Einführung in die symbolisch-erzählende Theologie, s. 260.

39 Por. A. Napiórkowski, Jezus Chrystus objawiony i objawiajacy. Chrystologia fundamentalna, Wydawnictwo WAM, Kraków 2008. 
cia konkretnej jednostki, co w jedynie ograniczonym stopniu daje możliwość stwierdzenia, czy taka narratywna nowa interpretacja tradycyjnego związku symbolicznego jest zasadniczo dopuszczalna, czy też sprzeciwia się ona istotnym i jednoznacznym historycznym bądź też chrześcijańskim regułom opowiadania (dogmaty). W pewnym sensie jest to trudny do uchwycenia i jednoznacznej interpretacji punkt styku praw jednostki i społeczności.

Właściwy proces korelacji pomiędzy historycznie i tradycyjnie przekazanymi symbolami a osobistą historią życia dokonuje się w rodzinie, w grupie przyjaciół, w grupie katechizacyjnej. Otwartym pozostaje problem, czy proces stapiania się własnego, aktualnego życia z przekazanym w ramach tradycji symbolem wiary i otwierające się przed człowiekiem wierzącym odczucia dotyczące wartości i życiowe perspektywy pozwalają przemówić Mesjaszowi Jezusowi w konkretnym życiu - czy też dochodzi do psychologicznie bądź socjologicznie uwarunkowanej iluzji. Rodzi się tu konieczność upewnienia się w wymiarze intersubiektywnym. Wymiana z innymi ludźmi własnych doświadczeń nabytych w trakcie osobistego procesu korelacji obiektywnych symboli wiary ze światem swojej egzystencji pozwala umocnić subiektywną pewność wiary. Następuje wtedy doniosły proces komunikacji wiary, dzięki któremu chrześcijanin może zaufać uzyskanemu przez siebie nowemu poznaniu i związanemu z tym poczuciu sensu. Zdolność komunikowania stanowi wprawdzie formalne, jednakże konieczne kryterium ortodoksji uzyskanej w ramach procesu korelacji subiektywnej pewności wiary ${ }^{40}$.

\subsection{O procesie komunikacji: od języka dogmatu do języka symbolu}

W swojej książce Georg Baudler ${ }^{41}$ podejmuje próbę wykazania, iż wszystkie istotne części składowe chrześcijańskiej tradycji, od trynitologii po mariologię, mogą być pojęte jako zespoły symboli, które, wychodząc od centrum, jakim jest Mesjasz Jezus, i prowadząc z powrotem ku Niemu, chrześcijanin integruje w swoje życie, dokonując tego w światopoglądowo zróżnicowanym społeczeństwie, każdy na swój sposób, w kreatywnej wymianie z innymi. Znaczącą rolę odgrywa tu rzeczywistość i pojęcie symbolu, otwierające drogę tej kreatywnej i naznaczonej osobistą biografią aktywności, polegającej na przyswojeniu religijnej tradycji. Symbol nie jest czymś, co ex definitione byłoby sprzeczne z osobistym spotkaniem i doświadczeniem Boga w Jezusie, lecz o wiele bardziej powinien być on pojmowany jako otwierający drogę ku temu spotkaniu i doświadczeniu w zsekularyzowanej sytuacji życia i rozmowy.

Symboliczno-opowiadające podejście do tradycji chrześcijańskiej otwiera perspektywy pozwalające w nowy sposób, z własnej perspektywy życiowej, spoj-

\footnotetext{
${ }^{40}$ Por. G. Baudler, Einführung in die symbolisch-erzählende Theologie, s. 263-264.

${ }^{41}$ Por. tamże.
} 
rzeć na to, co tworzy chrześcijaństwo, by móc świadomie włączyć się w urzeczywistnienie własnego bycia chrześcijaninem, i to w warunkach sekularyzującego i pluralizującego się świata ${ }^{42}$. Można to dostrzec na przykładzie mariologii. Otóż mariologia narracyjna wskazuje na ograniczenia mariologii argumentującej za pomocą typowych dla klasycznej teologii ścisłych terminów naukowych ${ }^{43}$. Istnieje możliwość mariologii narracyjnej, wykorzystującej sposób prezentacji prawdy teologicznej w analogii do biblijnego toku narracji, dotyczącego działania Boga, Jezusa Chrystusa i Maryi. Cechą mariologii narracyjnej jest nieufność względem pojęć klasycznej mariologii podręcznikowej, nad które przedkłada ona przeżycia i doświadczenia, przekonująco przekazywane, co miałoby zastąpić argumentację. Zdarzenia mają stać się obecne dzięki „opisowej mocy” narracji. Metoda ta ma na celu właściwe odczytanie narracji biblijnej o obecności Maryi w życiu Jezusa Chrystusa oraz Kościoła - tak pierwotnego, jak i współczesnego ${ }^{44}$.

Jednak początkiem i trwałym, żywym centrum chrześcijańskiego świata symboli pozostaje historia i los Jezusa z Nazaretu. Teologia narracyjna pyta o możliwość, dzięki której ze spotkania z ukrzyżowanym Jezusem powstaje zbawczo-wyzwalający świat symboliczny. Doświadczenie to nie może zostać zredukowane do poziomu ogólnych zasad, pryncypiów czy też podobnych doświadczeń i w ten sposób wytłumaczone. To doświadczenie musi zostać wykonane, aby dokonało się spotkanie $\mathrm{z}$ historycznie niepowtarzalną postacią Jezusa z Nazaretu, zawierającą zawsze owo więcej w stosunku do samych realiów historycznych, a co oznacza wiarę w Jezusa jako Chrystusa, Mesjasza Boga żyjącego. W Ukrzyżowanym ludzkość otrzymała nowy i dotychczas niemożliwy do wyobrażenia symbol Boga. Niezwykłość tego nowego symbolu polega na tym, że nie ma już więcej konieczności rozróżniania pomiędzy symbolem a symbolizowanym: w ukrzyżowanym, poniżonym, umarłym, a potem wskrzeszonym do życia przez Ojca Jezusie z Nazaretu mamy do czynienia z rzeczywistością samego Boga. Jest to absolutny, nieprzewyższalny, całkowicie adekwatny symbol Boga, w niczym niezredukowany i niczym niezakłócony wyraz istoty samego Boga. W tym znaczeniu żywy Jezus z Nazaretu, spotykający się z człowiekiem, stanowi historyczny fundament, zasadnicze i integrujące centrum wiary chrześcijańskiej ${ }^{45}$.

${ }^{42}$ Por. I. Bokwa, Teologia w warunkach nowoczesności i ponowoczesności, s. 174-180, 231-249.

${ }^{43}$ Por. Pontificia Academia Mariana Internationalis, La Madre del Signore. Memoria - presenza - speranza. Alcune questioni attuali sulla figura e la missione della Vergine Maria, PAMI, Città del Vaticano 2000.

${ }^{44}$ Por. S. Napiórkowski, Mariologia, w: Encyklopedia katolicka KUL, t. 11, red. S. Wilk i in., Towarzystwo Naukowe KUL, Lublin 2006, kol. 1377.

${ }^{45}$ Por. G. Baudler, Einführung in die symbolisch-erzählende Theologie, s. 88-91. Por. także: K. Rahner, Zur Theologie des Symbols, w: tenże, Schriften zur Theologie, t. IV, Benziger Verlag, Einsiedeln - Zürich - Köln 1967, s. 275-311. 


\section{Teologia Karla Rahnera i teologia narracyjna a refleksja nad imieniem Jezus: wnioski}

Teologia narracyjna doskonale wyczuwa ducha czasu. Słusznie dostrzega ona, iż nieodwołalnie skończył się czas przekazywania wiary w postaci suchych, dogmatycznych formuł. Karl Rahner dostatecznie jasno uświadomił konieczność antropologicznego zwrotu w teologii: wszelka teologia ma stać się antropologią, czyli taką teologią, która pyta o adresata teologicznego przesłania, a więc o człowieka żyjącego tu i teraz, w konkretnej, stale zmieniającej się sytuacji egzystencjalnej ${ }^{46}$. Tak więc katecheza i duszpasterstwo powinny dzisiaj bardziej niż dotychczas wychodzić od zsekularyzowanej, światopoglądowo pluralnej sytuacji rozmowy z adresatem swojego przesłania. Chodzi o umiejętność obchodzenia się z teologią symboliczno-opowiadającą jako sposobem podejścia do chrześcijańskiej tradycji. Zdolność tego rodzaju jest istotna dla wszystkich, którzy chrześcijańską tradycję pragną artykułować w dobie kulturowej ponowoczesności. Dla człowieka początku XXI wieku Jezus z Nazaretu nie jest w pierwszym rzędzie ani konkretnym, historycznym człowiekiem, z którym od ponad dwóch tysięcy lat łączą go osobiste odniesienia, ani też nie jest godnym uwielbienia Bogiem. Obie te właściwości muszą dopiero ukazać się w pełnym blasku w trakcie duszpasterskiej i katechetycznej pracy. Dla człowieka, przeciętnego człowieka z ulicy, powracającego z pracy czy też dla klasy szkolnej po fizyce Jezus jest przekazaną w ramach religijnej tradycji postacią, która w chrześcijańskich Kościołach, w chrześcijańskich kręgach dyskusyjnych, w chrześcijańskim ukształtowaniu życia została uczyniona centrum medytacji i orientacji życiowej. W zsekularyzowanym społeczeństwie każdy człowiek musi ciągle i na nowo znajdować i przebywać drogę od fenomenu Jezusa z Nazaretu (jako przekazanej drogą tradycji postaci religijnej) ku zbawczo-pocieszającemu uobecnieniu tego Jezusa jako Mesjasza oraz Jego życia i Jego świata. Jest to więc odniesienie do teologicznego jądra systematycznej refleksji nad imieniem Jezus. Spotkanie, obecność Jezusa, stanowią doświadczenie Boga, które nie może zostać utrwalone, lecz musi być ono w pewnym sensie wydobyte z każdej fazy życia oraz z każdej egzystencjalnej sytuacji życiowej. Nie da się zaprzeczyć, ze teologia narracyjna kontynuuje i rozwija najważniejsze wątki Rahnerowskiej chrystologii i antropologii transcendentalnej, zainteresowanych żywym, egzystencjalnym związkiem pomiędzy Jezusem Chrystusem a człowiekiem, pomiędzy chrystologią a antropologią ${ }^{47}$.

${ }^{46}$ Por. K. Rahner, Probleme der Christologie von heute, w: tenże, Schriften zur Theologie, t. I, Benziger Verlag, Einsiedeln - Zürich - Köln 1954, s. 169-222.

47 Por. I. Bokwa, Christologie als Anfang und Ende der Anthropologie. Über das gegenseitige Verhältnis zwischen Christologie und Anthropologie bei Karl Rahner; tenże, Relacja chrystologii $i$ antropologii jako model interpretacyjny teologii Karla Rahnera, ,Studia Theologica Varsaviensia” 31(1993), nr 2, s. 27-37. 
W akcie wiary człowiek przyjmuje do swojego życia Jezusa niosącego Boże zbawienie.

Teologia narracyjna podejmuje śmiałą próbę ogarnięcia całości chrześcijańskiego przekazu z perspektywy ludzkiego doświadczenia egzystencjalnego. Wynikiem tej próby jest nowa struktura nadana chrześcijańskiej tradycji. Jest to konieczne, aby móc mówić o nowej teologii. Nie wystarczy tu rozumienie teologii jako jedynie metody. Nie chodzi tu bowiem o już gotową, jedynie zmodyfikowaną z myślą o popularnym odbiorcy, utylitarną wersję teologii, lecz o uwzględniającą chrześcijańską dorosłość poszczególnego wierzącego, o jego chrześcijańskie uzdolnienie do tworzenia mowy i posługiwania się nią, a przy tym o nową postać teologii. Nie wymaga ona specjalnego, naukowego przygotowania w tej dziedzinie: główną troską symboliczno-opowiadającej teologii jest jej zbliżenie się do mowy i działania realnego człowieka wierzącego. Pozwala to otwierać nowe treści wiary przez umieszczanie ich w nowych strukturach, co z kolei skutkuje pogłębioną teologiczną samoświadomością oraz nową, bardziej wolną i kreatywną praktyką symboliczno-opowiadającej teologii.

Za zasadnicze elementy składowe projektu teologii narracyjnej należy uznać teologiczno-systematyczne wyjaśnienie opowiadania jako nakierowanego na zagadnienie czasu (Johann Baptist Metz), na ile opowiadanie w swej istocie mierzy się z problematyką czasu (Paul Ricoeur), jak również interdyscyplinarność opowiadania, w którym - podobnie jak w żydowsko-chrześcijańskim opowiadaniu - krzyżują się historyczne i fikcyjne sposoby opowiadania, prowadząc dialog z historiografią i teorią literatury. Do tego dochodzi kwestia relacji opowiadania do argumentacji; jeśli opowiadanie rzeczywiście wykazuje semantyczną, innowacyjną i teoriopoznawczą jakość (Paul Ricoeur), to czy na tej podstawie można stwierdzić, że jest ono także prymarnym materiałem dla dalszej teologicznej dyskusji.

Teologia narracyjna nie jest bynajmniej projektem skończonym, jako że wymaga ona jeszcze dalszego doprecyzowania i rozbudowy. Należy na przykład rozważyć problem relacji pomiędzy narracyjną strukturą głębi żydowsko-chrześcijańskiej tradycji a gatunkami opowiadania, jakie znajdujemy w tekstach biblijnych i teologicznych. Ze swoim konceptem otwartego opowiadania teologia narracyjna stawia istotne pytanie pod adresem koncepcji zamkniętego Objawienia $^{48}$. Teologię narracyjną można rozumieć jako szansę odnowienia ciągle jeszcze żywego projektu teologii hermeneutycznej, a więc teologii żywo zainteresowanej wyjaśnianiem, przekładaniem, czynieniem bardziej zrozumia-

${ }^{48}$ Por. K. Müller, Bedingungen einer Erzählkultur, w: Erzählter Glaube - erzählende Kirche, red. R. Zerfaß, Verlag Herder, Freiburg - Basel - Wien 1988, s. 28-51. Por. także: A. Napiórkowski, Jezus Chrystus objawiony i objawiajacy. Chrystologia fundamentalna. 
łymi tekstów - w znaczeniu formuł i symboli wiary - teologii pojmującej swoją istotę jako sztukę i naukę wyjaśniania i wykładania tekstów ${ }^{49}$.

Zarówno transcendentalna chrystologia Karla Rahnera, jak i teologia narracyjna stanowią we współczesnej teologii systematycznej przykłady dowartościowania elementu ludzkiego jako integralnego składnika teologii. Te poszukiwania i usiłowania są jednocześnie wkładem w teologiczne pogłębienie znaczenia imienia Jezus, streszczającego całość Jego ziemskiej misji, polegającej na szukaniu i zbawianiu człowieka. Przyczyną narzędziową Bożego zbawienia jest natura ludzka, a konkretniej biorąc - ludzka rzeczywistość Jezusa z Nazaretu.

\section{Impulses of Karl Rahner's SJ (1904-1984) theological thoughts and narrative theology in direction of deepening theological name of Jesus}

\section{Summary}

The theological dimension of the name of Jesus is not only a domain of biblical teaching, patrology, theology of spirituality or theology of liturgy. It is also a field for reflection of systematic theology. This study starts with a brief theological analysis of the name of Jesus and states that this is a summary of His earthy mission which is a saving mission to man and the world. Karl Rahner's contribution to contemporary christological reflection is hard to overestimate. His so-called transcendental christology is an attempt to include anthropology into the structure of theology as its integral component. In contrast, narrative theology deals with modern man as the addressee of the Christian message about salvation. It develops particular ways of access by a man, who is not a believer, to the Person and work of Jesus of Nazareth as the true and living Son of God.

\section{Keywords}

the name of Jesus, systematic theology, christology, soteriology, Karl Rahner, narrative theology, symbolic theology

\section{Słowa kluczowe}

imię Jezus, teologia systematyczna, chrystologia, soteriologia, Karl Rahner, teologia narracyjna, teologia symboliczna

\section{Bibliografia}

Baudler G., Wahrer Gott als wahrer Mensch. Entwürfe zu einer narrativen Christologie, Verlag Kösel, München 1977.

Baudler G., Einführung in die symbolisch-erzählende Theologie. Der Messias Jesus als Zentrum der christlichen Glaubenssymbole, Verlag Ferdinand Schöningh, Paderborn 1982.

${ }^{49}$ Por. W. Beinert, Hermeneutik, w: Lexikon der katholischen Dogmatik, s. 252-255. 
Beinert W., Hermeneutik, w: Lexikon der katholischen Dogmatik, red. tenże, Verlag Herder, Freiburg - Basel - Wien 1988, s. 252-255.

Biser E., Narrativität als Weg zur Identität. Zu Georg Baudlers Entwurf einer narrativen Christologie, ,Zeitschrift für Katholische Theologie” (1981) nr 1, s. 56-59.

Bokwa I., Christologie als Anfang und Ende der Anthropologie. Über das gegenseitige Verhältnis zwischen Christologie und Anthropologiebei Karl Rahner, Verlag Peter Lang, Frankfurt am Main - Bern - New York - Paris 1990.

Bokwa I., Relacja chrystologii i antropologii jako model interpretacyjny teologii Karla Rahnera, „Studia Theologica Varsaviensia” 31(1993), nr 2, s. 27-37.

Bokwa I., Wprowadzenie do teologii Karla Rahnera, Wydawnictwo Diecezji Tarnowskiej BIBLOS, Tarnów 1996.

Bokwa I., Teologia $w$ warunkach nowoczesności i ponowoczesności, Wydawnictwo Diecezjalne w Sandomierzu, Sandomierz 2010.

Comstock G.L., Two Types of Narrative Theology, „Journal of the American Academy of Religion” 55(1987), s. 687-717.

Denzinger H., Enchiridion symbolorum, definitionum et declarationum de rebus fidei et morum, P. Hünermann, H. Hoping (Hg.), Verlag Herder, Freiburg im Breisgau - Basel - Rom - Wien 2001.

Friedmann E.H., Christologie und Anthropologie. Methode und Bedeutung der Lehre vom Menschen in der Theologie Karl Barths, Vier - Türme - Verlag, Münsterschwarzach 1972.

Góźdź K., Teologia człowieka. Z najnowszej antropologii niemieckiej, Wydawnictwo KUL, Lublin 2006.

Granat W., Antropologia - teologiczna, C.: Antropologia systematyczna, w: Encyklopedia Katolic$k a$, t. I, red. F. Gryglewicz, R. Łukaszyk, Z. Sułowski, Wydawnictwo Towarzystwa Naukowego KUL, Lublin 1973, kol. 698-702.

Grözinger A., Erzählen und Handeln. Studien zu einer trinitarischen Grundlegung der praktischen Theologie, Chr. Kaiser Verlag, München 1989.

Joha Z., Christologie und Anthropologie. Eine Verhältnisbestimmung unter besonderer Berücksichtigung des theologischen Denkens Walter Kaspers, Verlag Herder, Freiburg - Basel - Wien 1992.

Knoepffler N., Der Begriff ,,transzendental” bei Karl Rahner. Zur Frage seiner Kantischen Herkunft, Tyrolia - Verlag, Innsbruck - Wien 1993.

Kowalczyk S., Filozoficzne idee postmodernizmu, Polskie Wydawnictwo Encyklopedyczne POLWEN, Radom 2004.

Lash N., Theology on the Way to Emmaus, SCM Press, London 1986.

Lohfink G., Erzählen als Theologie. Zur sprachlichen Grundstruktur der Evangelien, „Stimmen der Zeit" 192(1974), s. 521-532.

Löser W., Ekklesiologie, w: Lexikon der katholischen Dogmatik, red. W. Beinert, Verlag Herder, Freiburg - Basel - Wien 1988, s. 116-117.

McFague S., Metaphorical Theology, SCM Press, London 1983.

Metz J.B., Antropocentrismo cristiano. Studio sulla mentalità di Tommaso d'Aquino, tlum. A. Audisio, Borla Editore Torino, Torino 1969.

Müller K., Bedingungen einer Erzählkultur, w: Erzählter Glaube - erzählende Kirche, red. R. Zerfaß, Verlag Herder, Freiburg - Basel - Wien 1988, s. 28-51.

Napiórkowski A., Jezus Chrystus objawiony i objawiajacy. Chrystologia fundamentalna, Wydawnictwo WAM, Kraków 2008.

Napiórkowski A., Bosko-ludzka wspólnota. Podstawy katolickiej eklezjologii integralnej, Wydawnictwo WAM, Kraków 2009. 
Napiórkowski S., Mariologia, w: Encyklopedia katolicka KUL, t. 11, red. S. Wilk i in., Towarzystwo Naukowe KUL, Lublin 2006, kol. 1371-1379.

Peukert H., Wissenschaftstheorie - Handlungstheorie - Fundamentale Theologie, Patmos Verlag, Düsseldorf 1976.

Pontificia Academia Mariana Internationalis, La Madre del Signore. Memoria - presenza - speranza. Alcune questioni attuali sulla figura e la missione della Vergine Maria, PAMI, Città del Vaticano 2000.

Rahner K., Geist in Welt. Zur Metaphysik der endlichen Erkenntnis bei Thomas von Aquin, Verlag Felizian Rauch, Innsbruck 1939

Rahner K., Hörer des Wortes. Zur Grundlegung einer Religionsphilosophie, Verlag Kösel-Pustet, München 1941.

Rahner K., Probleme der Christologie von heute, w: tenże, Schriften zur Theologie, Bd. I, Benziger Verlag, Einsiedeln 1954, s. 169-222.

Rahner K., Zur Theologie des Symbols, w: tenże, Schriften zur Theologie, Bd. IV, Benziger Verlag, Einsiedeln 1959, s. 275-311.

Rahner K., Theologie und Anthropologie, w: tenże, Schriften zur Theologie, t. VIII, Benziger Verlag, Einsiedeln 1967, s. 43-65.

Rahner K., Potentia oboedientialis, w: Sacramentum Mundi, t. III, red. K. Rahner, A. Darlap, Verlag Herder, Freiburg/Br. 1969, kol. 1245-1249.

Rahner K., Anthropologie (Theologische), w: Lexikon für Theologie und Kirche, t. I, J. Hofer, red. K. Rahner, Verlag Herder, Freiburg in Breisgau, Freiburg/Br. 1986², kol. 623.

Ricoeur P., Le sujet convoquè, ,Revue de l'Institut Catholique” 28(1988), s. 83-99.

Ricoeur P., Zeit und Erzählung, t. 1-3, tłum. A. Knop, Verlag Fink, München 1988-1991.

Verweyen H., Wie wird ein Existential übernatürlich? Zu einem Grundproblem der Anthropologie K. Rahners, „Trierer Theologische Zeitschrift“ 95(1986) z. 2, s. 115-131.

Wenzel K., Narrative Theologie, w: Lexikon für Theologie und Kirche, red. W. Kasper, t. 7, Verlag Herder, Freiburg - Basel - Rom - Wien 1998, kol. 640-643.

Wilkoszewska K., Wariacje na ponowoczesność, Wydawnictwo Universitas, Kraków 2008. 